\title{
Unimodal relationship between biomass and species richness of deep-sea nematodes: implications for the link between productivity and diversity
}

\author{
Daniel Leduc ${ }^{1,2, *}$, Ashley A. Rowden ${ }^{2}$, David A. Bowden ${ }^{2}$, P. Keith Probert ${ }^{1}$, \\ Conrad A. Pilditch ${ }^{3}$, Scott D. Nodder ${ }^{2}$ \\ ${ }^{1}$ Department of Marine Science, University of Otago, PO Box 56, Dunedin, New Zealand \\ ${ }^{2}$ National Institute of Water and Atmospheric Research (NIWA) Ltd, Private Bag 14-901, Kilbirnie, Wellington 6021, \\ New Zealand \\ ${ }^{3}$ Department of Biological Sciences, University of Waikato, Private Bag 3105, Hamilton, New Zealand
}

\begin{abstract}
Describing large-scale patterns of biological diversity is a first step towards understanding the mechanisms that generate and maintain diversity. The highly diverse deep-sea floor is the largest ecosystem on Earth, but the productivity-diversity relationship in this biome is not well characterized. We investigated this relationship by using biomass of nematodes as a proxy for productivity (particulate organic carbon flux to the seabed). We used sample data collected from the New Zealand and Antarctic regions and combined these with published data from around the globe for broader analyses. There was a significant unimodal relationship between nematode biomass and diversity, i.e. expected number of species, ES(51) both within the New Zealand region and across ocean basins. This relationship remained significant after accounting for the effects of both water depth and nematode abundance. These findings support earlier suggestions of a unimodal productivity-diversity relationship in the deep sea that were based on other proxies (e.g. water depth, modelled particulate organic carbon flux). We argue that the 'productivity context' is of primary importance when determining the strength and nature of the relationship between other environmental factors and diversity. Studies that include either or both extremes of the productivity scale are likely to find that productivity is the main factor limiting deep-sea diversity, whereas those focusing on the intermediate productivity range are more likely to find that other factors (e.g. disturbance, habitat heterogeneity) play a role.
\end{abstract}

KEY WORDS: Southwest Pacific $\cdot$ Kaikoura Canyon $\cdot$ Ross Sea $\cdot$ Southern Ocean $\cdot$ Nematodes · Macroecology $\cdot$ Biomass

\section{INTRODUCTION}

Two major goals of ecology are to describe and explain patterns of species diversity (Lawton 1996). Species-energy theories, which have drawn considerable attention from ecologists seeking to explain large-scale diversity patterns, posit that species diversity (i.e. richness) is a function of one or multiple forms of energy variable(s) (e.g. temperature, evapo- transpiration, productivity; e.g. Currie 1991). The relationship between productivity and species diversity, in particular, has been the topic of numerous investigations in both terrestrial and aquatic ecosystems (Huston 1994, Rosenzweig 1995, Tittensor et al. 2011). Most such studies describe a unimodal relationship between productivity and local diversity (Waide et al. 1999, Dodson et al. 2000, Chase \& Leibold 2002), but positive and negative linear relation- 
ships are also common (Mittelbach et al. 2001, Witman et al. 2008). A number of underlying mechanisms have been proposed to explain productivitydiversity relationships, although there is much debate about their relative contributions (Rosenzweig 1992, Waide et al. 1999, Gross \& Cardinale 2007). As the number of individuals increases with productivity, diversity may increase through higher proportions of rare (Preston 1962) and specialist species (Evans et al. 2006), lowered extinction rates and/or higher speciation rates (Rex 1973, Wright 1983). Negative productivity-diversity relationships may result from increased rates of competitive exclusion (Grime 1973, Rosenzweig \& Abramsky 1993), temporal variability in productivity (Chown \& Gaston 1999) or environmental stress (e.g. hypoxia, Levin \& Gage 1998). A combination of these mechanisms, operating to increase and decrease diversity, might be responsible for the unimodal productivity-diversity relationship often observed.

Most of our knowledge of productivity-diversity relationships has been gained from terrestrial and shallow aquatic habitats (e.g. Mittelbach et al. 2001). Such relationships, however, have not been well characterized in the deep sea (>200 m water depth) owing to the challenges of conducting research in this environment and despite this ecosystem being the largest in areal extent on Earth. With the exception of chemosynthetic habitats, productivity in the deep sea is defined as particulate organic carbon (POC) flux from the euphotic zone. However, direct measurements of POC flux are rare. Consequently, investigations of productivity-diversity relationships in the deep sea are almost always conducted using productivity proxies. A decade ago, Levin et al. (2001, p. 60) noted that 'a unimodal relationship between diversity and productivity at large scales in the deep sea is plausible, but is not well substantiated'. This view remains essentially unchanged (Rex \& Etter 2010), although some support was provided in a recent study by Tittensor et al. (2011), which showed a unimodal relationship between modelled POC flux and the diversity of deep-sea protobranch bivalves and gastropods.

One of the main problems with investigating productivity-diversity relationships in the deep sea is the difficulty of placing available studies on a continuous productivity gradient (Levin et al. 2001, Rex \& Etter 2010). Most deep-sea studies are restricted to a single region, which limits the range of productivities sampled. The shape of the productivity-diversity relationship, however, may depend on the range of productivities considered (Huston 1999), which could explain inconsistencies between studies (Rex \& Etter 2010). Comparisons between investigations are also hampered by the wide range of productivity proxies used, such as water depth (e.g. Stuart \& Rex 2009), latitude (e.g. Lambshead et al. 2002), modelled surface water productivity (e.g. Corliss et al. 2009), modelled POC flux (e.g. O'Hara \& Tittensor 2010) or the organic matter/pigment content of the sediment itself (e.g. Berkenbusch et al. 2011, Leduc et al. 2012). Water depth is by far the most commonly used proxy for productivity because it is easy to determine, but depth is correlated with a number of other variables which can influence diversity patterns (e.g. temperature) and is not necessarily correlated directly with productivity at the seabed, particularly when compared across ocean basins (Rex \& Etter 2010). Remotely sensed and modelled data have also become increasingly popular, despite limitations associated with spatial/temporal resolution and model validation (Balch et al. 1992, Banse \& Postel 2003). POC flux to the seafloor depends on a variety of factors not included in these models, such as bottom micro- (Snelgrove et al. 1994) and macro-topography (e.g. canyons; De Leo et al. 2010), POC input from advective currents (Nodder et al. 2007) and the efficiency with which organic matter is remineralized and consumed in the water column (Buesseler et al. 2007).

Determining the relationship between productivity and local diversity at large spatial scales requires a proxy that can be meaningfully compared between ocean basins. Deep-sea standing stocks (i.e. biomass, abundance) of macrofauna (DeMaster et al. 1994, Cosson et al. 1997, Smith et al. 1997, Johnson et al. 2007) and meiofauna (Tietjen 1989, Danovaro et al. 1999) are strongly correlated with POC flux and could provide such a proxy (Rosenzweig 1995, Rex et al. 2005). Nematode biomass, in particular, is positively correlated with POC flux both within (Smith et al. 2008) and across ocean basins (Soetaert \& Heip 1995). Thus, whilst biomass is most commonly used as a measure of secondary productivity, there is evidence to suggest that it is also a good proxy for POC flux. As Rex \& Etter (2010, p. 25) noted, '[benthic] standing stock is the culmination of pelagic-benthic coupling, (...) and is the most directly relevant measure of ecological and evolutionary opportunity in the deep sea'. Few investigations, however, have been conducted on the relationship between standing stock and diversity (Haedrich et al. 1980, Boucher \& Lambshead 1995).

Nematodes are by far the most abundant component of deep-sea faunal communities (Giere 2009) 
and are arguably the most diverse (Lambshead \& Boucher 2003). However, our knowledge of nematode diversity trends in the deep sea remains sketchy relative to the larger macro- and megafauna. The majority of studies have reported a positive relationship between productivity and deep-sea nematode diversity (Lambshead et al. 2002, Lampadariou \& Tselepides 2006, Fonseca \& Soltwedel 2007, 2009, Danovaro et al. 2008a), although the opposite trend has also been reported (Gambi et al. 2003), and several studies found no depth-related diversity gradients (Dinet \& Vivier 1979, Jensen 1988, Lambshead et al. 2000). Whether these inconsistencies reflect the influence of other factors that have not been accounted for, or represent different portions of a larger unimodal curve, remains unclear. Nematodes are well suited for the study of diversity-productivity relationships in the deep sea because their standing stock is more closely linked to organic matter input than macrofauna and appears to be less affected by factors such as low oxygen conditions (Cook et al. 2000). Large-scale studies in the North Atlantic and the central Pacific have also led to the suggestion that, unlike larger organisms, nematode diversity in the deep sea is mostly unaffected by historical factors (e.g. glaciation events), which may otherwise confound analyses (Lambshead et al. 2000, 2002). Moreover, nematode biomass is typically estimated using the volumetric method (Giere 2009). This approach allows estimates of biomass and diversity to be derived from the same samples, thereby minimising any influence of small-scale variation in productivity.

The objective of the present study was to investigate the link between productivity and diversity in the deep sea by characterizing the relationship between nematode biomass and species richness. We used sample data collected from the New Zealand and Antarctic regions, and combined these with published data from the Mediterranean (Danovaro et al. 2008a, Pusceddu et al. 2009), Venezuela Basin (Tietjen 1984, 1989), Southeast Pacific (Danovaro et al. 2002, Gambi et al. 2003) and Southwest and central equatorial Pacific (Brown et al. 2001, Lambshead et al. 2002) for broader analyses.

\section{MATERIALS AND METHODS}

\section{Sampling and laboratory methods}

In total, 41 sites were sampled in the present study (Table 1, Fig. 1). New Zealand study sites (36 in total) were located on the Chatham Rise, Challenger
Plateau and Kaikoura Canyon. The Chatham Rise is a broad submarine ridge extending eastwards from the South Island of New Zealand at water depths of $\sim 350$ to $3000 \mathrm{~m}$. The highly productive Subtropical Front (STF) appears to be bathymetrically locked onto the southern flank of the rise near $44^{\circ} \mathrm{S}$ (Murphy et al. 2001, Sutton 2001). Meio- and macrofaunal biomass peaks on the southern flank of the rise near the STF and declines rapidly below $1200 \mathrm{~m}$ depth, particularly on the northern flank of the rise (Probert \& McKnight 1993, Nodder et al. 2003, Grove et al. 2006, Berkenbusch et al. 2011). Nine sites on the Chatham Rise were sampled in September to October 2001 along a transect at $178^{\circ} 30^{\prime} \mathrm{E}$ (350 to $3100 \mathrm{~m}$ water depth; Table 1) during National Institute of Water and Atmospheric Research (NIWA) cruise TAN0116 (Nodder et al. 2007). Sixteen sites (422 to $1238 \mathrm{~m}$ water depth) were sampled on the Chatham Rise in March to April 2007 during NIWA cruise TAN0705. One additional site (990 m water depth) was sampled in February 2009 during NIWA cruise TAN0902. This site is located in a large, near-circular depression ('pockmark', 10 km diameter, 80-100 m deep; Davy et al. 2010) on the southern flank of the rise and is characterized by episodic accumulations of fresh phytodetritus (S. Nodder unpubl. Ocean Survey 2020 data). The Challenger Plateau encompasses water depths $\sim 400$ to $3000 \mathrm{~m}$ in an area of generally low biological productivity to the northwest of the South Island, New Zealand (Murphy et al. 2001). Six sites (237 to $1213 \mathrm{~m}$ water depth) were sampled on the Challenger Plateau in May to June 2007 during NIWA cruise TAN0707. Five sites (405 to $1420 \mathrm{~m}$ water depth) were sampled along the Kaikoura Canyon axis in May 2010 during NIWA cruise TAN1006. The Kaikoura Canyon lies to the east of the South Island $\left(\sim 42^{\circ} \mathrm{S}\right)$, and has been described as one of the most productive deep-sea benthic habitats known (De Leo et al. 2010). Antarctic study sites included 2 sites on the Ross Sea continental shelf and slope (849 and $1604 \mathrm{~m}$ water depth, respectively), and 3 sites on the abyssal plain adjacent to Scott and Admiralty seamounts farther to the north (3245 to $3543 \mathrm{~m}$ water depth). These sites were sampled in February to March 2008 during NIWA cruise TAN0802. The abyssal site near Admiralty seamount is in an area of relatively lower surface productivity than the other Antarctic sites (Bowden et al. 2011).

Samples were taken using an Ocean Instruments MC-800A multicorer $\left(\mathrm{MUC}_{i}\right.$ core internal diameter $=$ $9.52 \mathrm{~cm}$ ). For faunal analyses, 1 to 2 replicates (i.e. samples from different MUC deployments) per site were obtained. Each faunal sample consisted of a 
Table 1. Details of study sites, with mean nematode abundance, biomass and diversity data ( $\mathrm{n}=1-5$ replicate samples). DW: dry weight; ES(51): expected number of species for a sample of 51 ind. Asterisks (*) are diversity data from Leduc et al. (2012)

\begin{tabular}{|c|c|c|c|c|c|c|c|}
\hline $\begin{array}{l}\text { Region } \\
\text { Voyage }\end{array}$ & Habitat & $\begin{array}{c}\text { Water } \\
\text { depth }(\mathrm{m})\end{array}$ & $\begin{array}{l}\text { Latitude } \\
\quad(\mathrm{S})\end{array}$ & $\begin{array}{l}\text { Longitude } \\
\text { (E or W) }\end{array}$ & $\begin{array}{l}\text { Abundance (ind. } \\
\text { per } 10 \mathrm{~cm}^{-2} \text { ) }\end{array}$ & $\begin{array}{l}\text { Biomass }(\mu \mathrm{g} \mathrm{DW} \\
\left.\text { per } 10 \mathrm{~cm}^{-2}\right)\end{array}$ & $\begin{array}{r}\text { Diversity } \\
(\mathrm{ES}(51))\end{array}$ \\
\hline \multicolumn{8}{|c|}{ New Zealand } \\
\hline \multirow[t]{9}{*}{ TAN0116 } & Chatham & 350 & $43^{\circ} 43.33^{\prime}$ & $178^{\circ} 50.00^{\prime} \mathrm{E}$ & 1355 & 168.5 & $36.7^{*}$ \\
\hline & Rise & 450 & $42^{\circ} 96.81^{\prime}$ & $178^{\circ} 50.00^{\prime} \mathrm{E}$ & 795 & 47.9 & $41.5^{*}$ \\
\hline & & 450 & $43^{\circ} 81.81^{\prime}$ & $178^{\circ} 50.00^{\prime} \mathrm{E}$ & 972 & 99.5 & $35.7^{*}$ \\
\hline & & 750 & $44^{\circ} 00.00^{\prime}$ & $178^{\circ} 50.00^{\prime} \mathrm{E}$ & 1314 & 70.7 & $38.3^{*}$ \\
\hline & & 1000 & $42^{\circ} 81.67^{\prime}$ & $178^{\circ} 50.00^{\prime} \mathrm{E}$ & 476 & 31.9 & $40.7^{*}$ \\
\hline & & 1200 & $44^{\circ} 33.33^{\prime}$ & $178^{\circ} 50.00^{\prime} \mathrm{E}$ & 1521 & 53.8 & $39.6^{*}$ \\
\hline & & 2300 & $42^{\circ} 30.00^{\prime}$ & $178^{\circ} 30.00^{\prime} \mathrm{E}$ & 391 & 31.2 & 37.6 \\
\hline & & 2800 & $46^{\circ} 40.00^{\prime}$ & $178^{\circ} 30.00^{\prime} \mathrm{E}$ & 239 & 13.2 & 34.7 \\
\hline & & 3100 & $41^{\circ} 00.00^{\prime}$ & $178^{\circ} 30.00^{\prime} \mathrm{E}$ & 165 & 17.9 & 38.6 \\
\hline \multirow[t]{15}{*}{ TAN0705 } & Chatham & 530 & $43^{\circ} 97.92^{\prime}$ & $179^{\circ} 63.33^{\prime} \mathrm{E}$ & 1711 & 129.2 & $32.8^{*}$ \\
\hline & Rise & 644 & $43^{\circ} 29.30^{\prime}$ & $175^{\circ} 54.53^{\prime} \mathrm{W}$ & 549 & 19.9 & $37.4^{*}$ \\
\hline & & 1016 & $42^{\circ} 78.60^{\prime}$ & $176^{\circ} 7149^{\prime} \mathrm{W}$ & 560 & 39.2 & $37.6^{*}$ \\
\hline & & 1210 & $42^{\circ} 62.16^{\prime}$ & $175^{\circ} 92.62^{\prime} \mathrm{E}$ & 1324 & 222.5 & $35.8^{*}$ \\
\hline & & 532 & $42^{\circ} 99.03^{\prime}$ & $178^{\circ} 98.64^{\prime} \mathrm{E}$ & 2487 & 229.1 & $38.4^{*}$ \\
\hline & & 515 & $44^{\circ} 13.01^{\prime}$ & $174^{\circ} 84.55^{\prime} \mathrm{E}$ & 2828 & 322.8 & $35.0^{*}$ \\
\hline & & 1238 & $44^{\circ} 48.64^{\prime}$ & $177^{\circ} 14.07^{\prime} \mathrm{E}$ & 1698 & 216.0 & $33.1^{*}$ \\
\hline & & 478 & $43^{\circ} 82.66^{\prime}$ & $176^{\circ} 70.43^{\prime} \mathrm{E}$ & 989 & 317.9 & $30.2^{*}$ \\
\hline & & 422 & $43^{\circ} 51.62^{\prime}$ & $178^{\circ} 61.67^{\prime} \mathrm{W}$ & 1109 & 149.0 & $37.2^{*}$ \\
\hline & & 770 & $44^{\circ} 01.68^{\prime}$ & $178^{\circ} 51.93^{\prime} \mathrm{E}$ & 1837 & 177.3 & $37.2^{*}$ \\
\hline & & 1200 & $42^{\circ} 61.16^{\prime}$ & $178^{\circ} 33.93^{\prime} \mathrm{W}$ & 889 & 39.8 & $40.0^{*}$ \\
\hline & & 792 & $42^{\circ} 76.15^{\prime}$ & $178^{\circ} 34.86^{\prime} \mathrm{W}$ & 598 & 23.4 & $37.9^{*}$ \\
\hline & & 980 & $42^{\circ} 78.18^{\prime}$ & $177^{\circ} 21.03^{\prime} \mathrm{W}$ & 222 & 7.7 & $36.7^{*}$ \\
\hline & & 896 & $42^{\circ} 80.80^{\prime}$ & $177^{\circ} 22.82^{\prime} \mathrm{W}$ & 226 & 10.9 & $37.9^{*}$ \\
\hline & & 799 & $42^{\circ} 84.68^{\prime}$ & $177^{\circ} 22.47^{\prime} \mathrm{W}$ & 376 & 15.6 & $33.8^{*}$ \\
\hline \multirow[t]{6}{*}{ TAN0707 } & Challenger & 480 & $38^{\circ} 61.82^{\prime}$ & $168^{\circ} 94.31^{\prime} \mathrm{E}$ & 669 & 37.2 & $40.3^{*}$ \\
\hline & Plateau & 1213 & $36^{\circ} 92.14^{\prime}$ & $167^{\circ} 52.56^{\prime} \mathrm{E}$ & 641 & 36.8 & $33.4^{*}$ \\
\hline & & 264 & $39^{\circ} 64.63^{\prime}$ & $172^{\circ} 15.30^{\prime} \mathrm{E}$ & 893 & 63.6 & $31.2^{*}$ \\
\hline & & 532 & $40^{\circ} 88.14^{\prime}$ & $170^{\circ} 86.03^{\prime} \mathrm{E}$ & 737 & 33.9 & $34.7^{*}$ \\
\hline & & 804 & $40^{\circ} 12.64^{\prime}$ & $170^{\circ} 22.17^{\prime} \mathrm{E}$ & 575 & 87.5 & $32.1^{*}$ \\
\hline & & 237 & $39^{\circ} 64.09^{\prime}$ & $172^{\circ} 37.15^{\prime} \mathrm{E}$ & 669 & 40.3 & $32.4^{*}$ \\
\hline TAN0902 & $\begin{array}{l}\text { Chatham Rise } \\
\text { 'pockmark' }\end{array}$ & 990 & $44^{\circ} 06.60^{\prime}$ & $178^{\circ} 35.62^{\prime} \mathrm{E}$ & 3269 & 719.5 & 26.4 \\
\hline \multirow[t]{5}{*}{ TAN1006 } & Kaikoura Canyon & 404 & $42^{\circ} 29.38^{\prime}$ & $173^{\circ} 33.06^{\prime} \mathrm{E}$ & 3315 & 304.7 & 12.2 \\
\hline & & 706 & $42^{\circ} 28.86^{\prime}$ & $173^{\circ} 33.49^{\prime} \mathrm{E}$ & 2801 & 161.7 & 11.5 \\
\hline & & 1017 & $42^{\circ} 29.03^{\prime}$ & $173^{\circ} 36.88^{\prime} \mathrm{E}$ & 3226 & 1326.5 & 16.6 \\
\hline & & 1061 & $42^{\circ} 30.49^{\prime}$ & $173^{\circ} 37.95^{\prime} \mathrm{E}$ & 1661 & 1352.9 & 21.5 \\
\hline & & 1320 & $42^{\circ} 31.42^{\prime}$ & $173^{\circ} 43.68^{\prime} \mathrm{E}$ & 2011 & 849.9 & 18.6 \\
\hline \multicolumn{8}{|l|}{ Antarctic } \\
\hline \multirow[t]{5}{*}{ TAN0802 } & $\begin{array}{l}\text { Ross Sea conti- } \\
\text { nental shelf }\end{array}$ & 849 & $74^{\circ} 43.92^{\prime}$ & $167^{\circ} 06.17^{\prime} \mathrm{E}$ & 7023 & 116.9 & 21.5 \\
\hline & $\begin{array}{l}\text { Ross Sea conti- } \\
\text { nental slope }\end{array}$ & 1604 & $72^{\circ} 05.30^{\prime}$ & $175^{\circ} 33.51^{\prime} \mathrm{E}$ & 777 & 23.2 & 29.8 \\
\hline & $\begin{array}{l}\text { Abyssal plain, near } \\
\text { Admiralty seamount }\end{array}$ & 3403 & $66^{\circ} 43.43^{\prime}$ & $171^{\circ} 11.18^{\prime} \mathrm{E}$ & 338 & 13.3 & 34.1 \\
\hline & $\begin{array}{l}\text { Abyssal plain, near } \\
\text { Scott seamount }\end{array}$ & 3245 & $67^{\circ} 37.18^{\prime}$ & $178^{\circ} 12.12^{\prime} \mathrm{W}$ & 236 & 22.2 & 31.4 \\
\hline & $\begin{array}{l}\text { Abyssal plain, near } \\
\text { Scott seamount }\end{array}$ & 3543 & $68^{\circ} 31.12^{\prime}$ & $178^{\circ} 48.70^{\prime} \mathrm{W}$ & 450 & 11.6 & 19.8 \\
\hline
\end{tabular}

subcore $(2.6 \mathrm{~cm}$ internal diameter) taken to a sediment depth of $5 \mathrm{~cm}$. All samples were preserved in $10 \%$ formalin and stained with Rose Bengal. Samples were rinsed through a $1 \mathrm{~mm}$ mesh to remove macrofauna and through a $45 \mu \mathrm{m}$ mesh to retain nematodes. Nematodes were extracted from the remaining sediment by Ludox flotation, transferred to pure glycerol and mounted on slides (Somerfield \& Warwick 1996).

All nematodes present in each sample were counted under a compound microscope at $100 \times$ magnification. Nematode body volumes were estimated from 




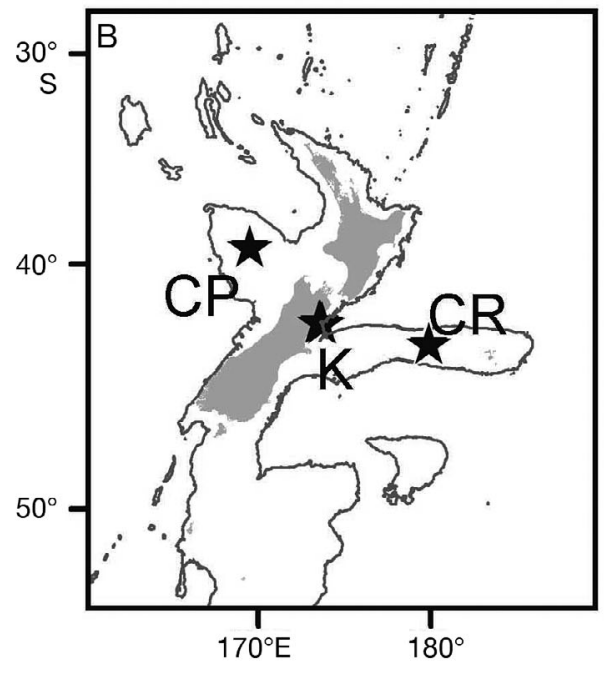

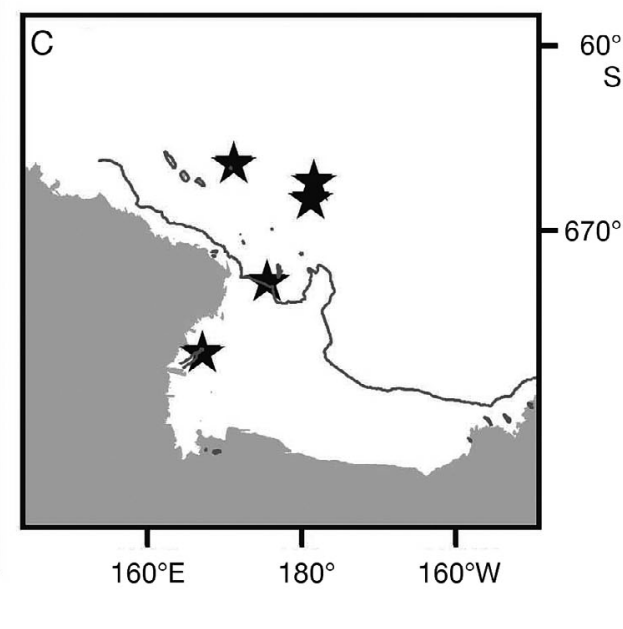

Fig. 1. Nematode sampling locations. (A) Locations of literature studies. Asterisk: Danovaro et al. (2008a), triangle: Pusceddu et al. (2009); diamond: Tietjen $(1984,1989)$; circle: Danovaro et al. (2002) and Gambi et al. (2003); square: Brown et al. (2001) and Lambshead et al. (2002). (B) New Zealand regional map, showing the 3 bathymetric features sampled for this study (stars; $\mathrm{CP}$ : Challenger Plateau, K: Kaikoura Canyon, CR: Chatham Rise). (C) Ross Sea regional map, showing sampling sites (stars) length and maximum body width measurements obtained by video image analysis (Nodder et al. 2003, Grove et al. 2006). Body volumes were converted to dry weight (DW) based on a relative density of 1.13, and a dry:wet weight ratio of 0.25 (Feller \& Warwick 1988). Estimates of mean body weight were based on a minimum of 100 individuals, or all individuals if fewer were present. Nematode diversity was estimated based on the identification of 120 to 150 randomly selected individuals (or all individuals if fewer were present) per sample and quantified using Hurlbert's (1971) rarefaction method for estimating the expected number of species for a sample of 51 individuals, ES(51). This measure is among the most commonly used diversity indices in deep-sea nematode investigations (e.g. Danovaro et al. 2008b) and allows comparison of samples with different abundances. Nematodes were identified to genus and putative species using descriptions of Warwick et al. (1998), as well as the primary literature.

\section{Literature data}

We collated data from all deep-sea studies for which nematode diversity expressed as ES(51) could be found and which also provided biomass and abundance data (Table 2). Data were obtained from the Mediterranean (12 sites; Danovaro et al. 2008a, Pusceddu et al. 2009), Venezuela Basin (8 sites; Tietjen 1984, 1989), central equatorial Pacific (5 sites; Brown et al. 2001, Lambshead et al. 2002) and southeast Pacific (4 sites; Danovaro et al. 2002, Gambi et al. 2003). Samples in these studies were obtained using either a multicorer or box corer (see Table 2 for details), which may yield different abundance estimates (Bett et al. 1994). Some studies, however, have reported no difference between the 2 sampling methods (Brown et al. 2001, Mokievskii et al. 2007). All of these studies sampled with a core $\leq 10 \mathrm{~cm}$ in diameter and determined biomass using the volumetric method (Giere 2009). All studies used a mesh 
Table 2. Details of literature data sources included in the study showing mean nematode abundance, biomass and diversity. DW: dry weight; ES(51): expected number of species for a sample of 51 ind. ${ }^{*}$ : from top $1 \mathrm{~cm}$ of sediments; ${ }^{* *}$ : estimated from graph; ${ }^{* * *}$ : from Danovaro et al. (2008b)

\begin{tabular}{|c|c|c|c|c|}
\hline $\begin{array}{l}\text { Region } \\
\text { Source }\end{array}$ & $\begin{array}{l}\text { Water } \\
\text { depth } \\
(\mathrm{m})\end{array}$ & $\begin{array}{l}\text { Abundance } \\
\text { (ind. per } \\
10 \mathrm{~cm}^{-2} \text { ) }\end{array}$ & $\begin{array}{l}\text { Biomass } \\
(\mu g \mathrm{DW} \\
\left.10 \mathrm{~cm}^{-2}\right)\end{array}$ & $\begin{array}{c}\text { Diversity } \\
(\mathrm{ES}(51))\end{array}$ \\
\hline \multicolumn{5}{|l|}{ Mediterranean } \\
\hline \multirow[t]{8}{*}{ Danovaro et al. (2008a) ${ }^{a}$} & 3870 & 45 & 3.6 & $16.9^{*}$ \\
\hline & 3055 & 38 & 0.8 & $16.2^{*}$ \\
\hline & 2950 & 74 & 3.0 & $19.8^{*}$ \\
\hline & 3200 & 109 & 6.6 & $21.0^{*}$ \\
\hline & 4000 & 33 & 2.0 & $22.0^{*}$ \\
\hline & 1290 & 326 & 65.1 & $26.8^{*}$ \\
\hline & 2850 & 161 & 12.9 & $23.0^{*}$ \\
\hline & 2755 & 92 & 11.0 & $23.9^{*}$ \\
\hline \multirow{4}{*}{ Pusceddu et al. (2009) ${ }^{\mathrm{a}}$} & 3581 & $32^{* *}$ & $0.6^{* *}$ & 15.0 \\
\hline & 3430 & $25^{* *}$ & $0.6^{* *}$ & 12.0 \\
\hline & 3550 & $55^{* *}$ & $7.0^{* *}$ & 20.3 \\
\hline & 3550 & $56^{* *}$ & $2.0^{* *}$ & 22.0 \\
\hline \multicolumn{5}{|l|}{ Venezuela Basin } \\
\hline \multirow{3}{*}{ Tietjen $(1984)^{\mathrm{b}}$} & 3858 & $65^{* *}$ & $32.0^{* *}$ & $27.4^{* * *}$ \\
\hline & 5054 & $38^{* *}$ & $30.0^{* *}$ & $32.1^{* * *}$ \\
\hline & 3517 & $90^{* *}$ & $88.0^{* *}$ & $31.8^{* * *}$ \\
\hline \multirow[t]{5}{*}{ Tietjen $(1989)^{\mathrm{b}}$} & 5401 & $137^{* *}$ & $15.5^{* *}$ & $30.0^{* * *}$ \\
\hline & 2217 & $92^{* *}$ & $5.2^{* *}$ & $26.8^{* * *}$ \\
\hline & 7460 & $76^{*}$ & $8.0^{* *}$ & $25.4^{* * *}$ \\
\hline & 8189 & $69^{* *}$ & $19.9^{* *}$ & $22.4^{* * *}$ \\
\hline & 8380 & $78^{* *}$ & $16.8^{* *}$ & $21.6^{* * *}$ \\
\hline \multicolumn{5}{|l|}{ Central equatorial Pacific } \\
\hline Lambshead et al. $(2002)^{\mathrm{c}}$ & 4320 & $60^{*}$ & $3.1^{*}$ & 33.9 \\
\hline \multirow[t]{4}{*}{ Brown et al. $(2001)^{\mathrm{C}}$} & 4400 & $96^{*}$ & $8.2^{*}$ & 32.4 \\
\hline & 4390 & $64^{*}$ & $8.7^{*}$ & 32.4 \\
\hline & 4990 & $45^{*}$ & $1.9^{*}$ & 31.3 \\
\hline & 4880 & $40^{*}$ & $1.9^{*}$ & 28.2 \\
\hline \multicolumn{5}{|l|}{ SE Pacific } \\
\hline Danovaro et al. $(2002)^{\mathrm{d}}$ & 1050 & 492 & 232 & 25.0 \\
\hline \multirow[t]{3}{*}{ Gambi et al. $(2003)^{\mathrm{d}}$} & 1140 & 550 & 248 & 26.7 \\
\hline & 1355 & 525 & 282 & 26.0 \\
\hline & 7800 & 5072 & 810 & 18.4 \\
\hline
\end{tabular}

${ }^{\mathrm{a}}$ Multicore, $20 \mu \mathrm{m}$ mesh; ${ }^{b}$ box core, $44 \mu \mathrm{m}$ mesh; ${ }^{\mathrm{c} m u l t i c o r e}$ and box core, $45 \mu \mathrm{m} \mathrm{mesh}$; ${ }^{\mathrm{d}}$ box core, $20 \mu \mathrm{m}$ mesh

assumed that biomass estimates were $33 \%$ of the total depth-integrated values (D. Leduc unpubl. data). All other diversity and biomass data were based on cores $\geq 5 \mathrm{~cm}$ deep.

\section{Statistical analyses}

Statistical analyses were conducted on the mean nematode biomass and diversity of each site. Analyses were conducted on all data combined $(\mathrm{n}=$ 70 samples) and on Chatham Rise sites only $(n=25)$, in order to compare the biomass-diversity relationship at different spatial scales (i.e. across and within regions). The Chatham Rise sites were chosen for separate analysis because they span a wide range of productivities within a single seabed feature.

Analyses were conducted using distance-based linear models (DistLMs) in PERMANOVA+ (Anderson et al. 2008). The DistLM routine is a semi-parametric, permutation-based method that does not rely on the assumption of normally distributed data (Anderson et al. 2008). Examination of predictor variables (i.e. water depth, nematode abundance and biomass) prior to analyses showed that they were not strongly correlated $\left(\mathrm{R}^{2}<0.41\right)$. Because water depth is the most commonly used productivity proxy in deep-sea studies (Rex \&

size of $45 \mu \mathrm{m}$ or less, which ensured minimal variation in biomass estimates since nematodes retained on a $45 \mu \mathrm{m}$ mesh comprise $>90 \%$ of total biomass in deep-sea samples (Leduc et al. 2010a,b). One study (Danovaro et al. 2008a) provided nematode diversity data only from the 0-1 cm sediment depth layer, while nematode abundance and biomass data were obtained from the $0-15 \mathrm{~cm}$ depth layer. Diversity estimates from Danovaro et al. (2008a) were adjusted assuming that diversity estimates based on the top $1 \mathrm{~cm}$ of sediments underestimate $\mathrm{ES}(51)$ values by $15 \%$ relative to whole cores (Leduc et al. 2010b). Another study (Lambshead et al. 2002) provided nematode diversity data based on whole cores (sediment depth not specified) but estimated biomass based on the 0-1 cm fraction only. In this case, we
Etter 2010), we began by investigating the relationship between water depth and nematode diversity. Nematode abundance was also included in the analyses to examine its relationship with diversity and to take into account its potential influence on the biomass-diversity relationship. Both linear and quadratic relationships were modelled in DistLM (the latter by performing regressions on first- and secondorder terms in sets, Anderson et al. 2008). The bestfitting relationship was chosen for the final regression models by comparing adjusted $\mathrm{R}^{2}$ values (Quinn $\&$ Keough 2009). Relationships between water depth, nematode abundance, nematode biomass and diversity were initially examined by analysing each predictor separately (marginal tests). Partial regressions were used to better characterize the relationships 
and to account for the effect of the other 2 variables. Similarity matrices used in DistLM analyses were built using Euclidean distance of untransformed diversity data (Anderson et al. 2008). The p-values for individual predictor variables were obtained using 9999 permutations. Water depth and nematode abundance/biomass data were $\log _{10}$-transformed to reduce skewness.

\section{RESULTS}

Nematode abundance and biomass at the New Zealand and Antarctic sites spanned about 1 and 3 orders of magnitude, respectively (Table 1). Nematode abundance was lowest at the deepest Chatham Rise site $\left(3100 \mathrm{~m}\right.$ water depth; 165 ind. $\left.10 \mathrm{~cm}^{-2}\right)$ and highest at the Kaikoura Canyon sites (1661-3315 ind. $10 \mathrm{~cm}^{-2}$ ). Biomass was lowest at sites on the northeastern Chatham Rise (7.7-15.6 $\mu \mathrm{g}$ DW $\left.10 \mathrm{~cm}^{-2}\right)$ and at the Southern Ocean abyssal sites (11.6-22.2 $\mu \mathrm{g}$ DW $10 \mathrm{~cm}^{-2}$ ). Nematode biomass was highest at the 3 deepest Kaikoura Canyon sites (850-1353 $\mu \mathrm{g}$ DW $\left.10 \mathrm{~cm}^{-2}\right)$. ES(51) was lowest at the 2 shallowest Kaikoura Canyon sites (11.5-12.2) and highest at 2 sites on the northern flank of the Chatham Rise (40.7-41.5).

The range of nematode abundance and biomass for New Zealand, Antarctic and literature data combined spanned 2 and 4 orders of magnitude, respectively (32-7023 ind. $10 \mathrm{~cm}^{-2}, 0.6-1353 \mu \mathrm{g}$ DW per $10 \mathrm{~cm}^{-2}$, Tables $1 \& 2$ ). There was a weak but statistically significant negative relationship between water depth and nematode diversity for all data combined $\left(p=0.002, R^{2}=0.14 ;\right.$ Table 3$)$ but not for the Chatham Rise sites alone $(p>0.05)$. Similarly, there was a significant quadratic relationship between nematode abundance and diversity for all data combined ( $\left.p=0.001, R^{2}=0.42\right)$ but not for the Chatham Rise sites alone $(p>0.05)$. There was a strong significant quadratic relationship between nematode biomass and diversity for all data combined and for Chatham Rise sites only $\left(R^{2}=0.46\right.$ and 0.63 , respectively, $p=$ 0.001; Fig. 2). These relationships remained significant after controlling for water depth and abundance (Table 3).

\section{DISCUSSION}

Describing large-scale diversity patterns is a first step towards understanding the mechanisms that generate and maintain diversity. Many deep-sea studies span a comparatively limited productivity range (i.e. $\leq 1$ order of magnitude; see Table 2). Combining data from oligotrophic (e.g. the Mediterranean) to highly eutrophic deep-sea habitats (e.g. Kaikoura Canyon) across a wide range of water depths (237$8380 \mathrm{~m}$ ) and regions enabled us to characterize the relationship between nematode biomass and local diversity across the broadest possible spectrum.

Using biomass as a proxy of productivity (i.e. POC flux) has several advantages. Biomass, for example, provides a way to scale studies on a continuous productivity gradient and, for nematodes at least, provides a measure of productivity at a directly relevant

Table 3. Results of distance-based linear model (DistLM) analyses between water depth, nematode abundance, nematode biomass and nematode diversity (expected number of species for a sample of 51 ind., ES(51), for all data combined, and for Chatham Rise sites only. Marginal tests examine a single predictor separately, while partial tests take into account the effect of the other 2 predictors. Correlations are for linear (water depth) and quadratic (nematode abundance and biomass) relationships. Variables that are significantly correlated with nematode diversity are shown in bold. Prop.: proportion of the total variation in diversity, ES(51); res.: residual; regr.: regression

\begin{tabular}{|llcccccc}
\hline & Variable & SS (trace) & Pseudo- $F$ & $p$ & Prop. & Res. df & Regr. df \\
\hline All data (marginal) & Depth & 569.7 & 10.887 & 0.002 & 0.14 & 68 \\
& Abundance & 1719.9 & 23.928 & 0.001 & 0.42 & 67 & 2 \\
& Biomass & 1987.5 & 31.108 & 0.001 & 0.46 & 67 & 3 \\
All data (partial) & Depth & 56.6 & 2.027 & 0.152 & 0.01 & 64 & 6 \\
& Abundance & 140.8 & 2.521 & 0.109 & 0.03 & 64 & 6 \\
& Biomass & 551.1 & 9.870 & 0.001 & 0.13 & 64 & 6 \\
Chatham only (marginal) & Depth & 1.3 & 0.112 & 0.752 & $<0.01$ & 23 & 2 \\
& Abundance & 59.7 & 3.195 & 0.071 & 0.23 & 22 & 3 \\
& Biomass & 167.5 & 18.818 & 0.001 & 0.63 & 22 & 3 \\
& Depth & 3.7 & 0.867 & 0.351 & 0.001 & 19 & 6 \\
& Abundance & 16.137 & 1.894 & 0.171 & 0.06 & 19 & 6 \\
& Biomass & 124.6 & 14.682 & 0.001 & 0.47 & 19 \\
\hline
\end{tabular}




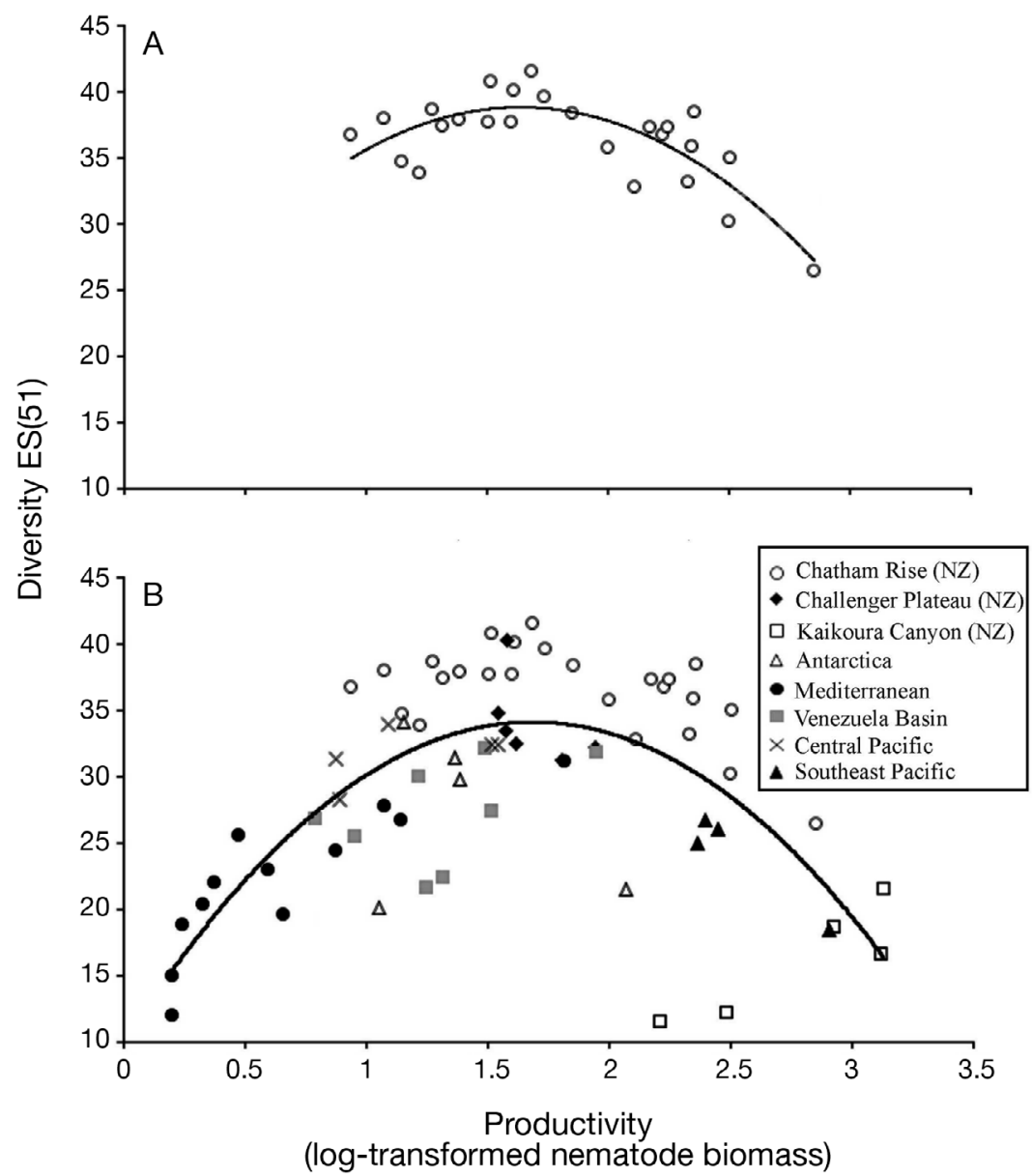

Fig. 2. Relationship between productivity, $\log _{10}(1+$ nematode biomass $)$, and nematode diversity, ES(51), on (A) the Chatham Rise and (B) across regions. Curved line in (B) shows the fit for all data points. See Table 3 for results of regressions analyses

spatial scale because the same sample is used for both biomass and diversity estimates. The latter is particularly important for small animals with limited mobility, such as nematodes, because their distribution is likely driven by local $(<10 \mathrm{~cm})$ environmental conditions (Gallucci et al. 2009). As stated earlier, the strong link between measured POC flux and deepsea benthic biomass is well established (e.g. Smith et al. 2008). In addition, nematode biomass on the Chatham Rise and Challenger Plateau is significantly correlated with other proxies of productivity, such as surface chlorophyll a concentrations $\left(\mathrm{R}^{2}=0.54, \mathrm{p}<\right.$ 0.01 ) and chloroplastic pigment concentrations in the sediments $\left(\mathrm{R}^{2}=0.67, \mathrm{p}<0.01\right.$; D. Leduc unpubl. data). Positive relationships between sediment pigment concentrations and nematode biomass have been described in other regions (e.g. Brown et al. 2001), providing further support for the use of nematode biomass as a proxy for productivity. Neverthe- less, biomass may be affected by factors other than productivity. Physical disturbance and predation, for example, could reduce biomass by removing individuals from the population. Quantifying the influence of these factors is difficult, but we might expect some habitats such as canyons to be subject to more intense disturbance regimes than open slope habitats (De Stigter et al. 2007, Garcia et al. 2007). Nematode biomass from the Kaikoura Canyon samples may, therefore, have been underestimated, although greater biomass values for this location would strengthen, rather than weaken, the unimodal relationship we observed (see Fig. 2).

Ideally, deep-sea productivity would be quantified using direct measurements of POC flux at a scale relevant to the system under study. Measuring POC flux in the deep sea, however, is labour-intensive, and site-specific data are generally scarce (e.g. Jahnke 1996, Lutz et al. 2007). Estimates of POC fluxes in the deep ocean from modelled (e.g. Usbeck et al. 2003) and satellite data (e.g. Lutz et al. 2007) are easier to obtain, but current methods do not take into account the potential decoupling between POC flux at the seabed and surface productivity (Buesseler et al. 2007), the influence of down-slope transport (Hecker 1990), lateral advection (Nodder et al. 2007), riverine input (Hansell et al. 2004) or bottom topography (e.g. canyons, Wei et al. 2010). It has also been argued that it is the quality rather than the quantity of the organic flux reaching the benthos that is critical in determining benthic secondary productivity (e.g. Nodder et al. 2003). Furthermore, parameters such as POC flux or sediment organic matter/pigment content do not take into account the partitioning of food resources between different components of the benthos. The relative contribution of smaller organisms to benthic secondary production, for example, increases substantially with depth (Rowe et al. 2008), implying that they incorporate varying proportions of available food resources.

The present study supports earlier suggestions of a unimodal productivity-diversity relationship in the 
deep sea that were based on water depth (Levin et al. 2001, Rex et al. 2005, Rex \& Etter 2010). The depthbased evidence for a unimodal productivity-diversity relationship in the deep sea showed a peak in diversity at intermediate depths (2000- 3000 m; Rex 1973, 1981, Etter \& Grassle 1992, Boucher \& Lambshead 1995, Rex et al. 2005), although positive and negative linear patterns have also been reported (see review by Stuart \& Rex 2009). Besides productivity, several other factors that can vary with depth, such as sediment particle size diversity (Etter \& Grassle 1992), macrohabitat heterogeneity (McClain \& Barry 2010), oxygen concentrations (Levin et al. 2001), predation (Rex 1976) and speciation rates (Zardus et al. 2006), could explain these depth-related patterns. In the present study, diversity was either not correlated (Chatham Rise) or only weakly correlated (all data) with water depth. This finding adds to previous concerns that depth is not a particularly useful proxy for productivity. More work is required to test the generality of the unimodal productivity-diversity relationship in the deep sea using other productivity proxies.

Our results, based on biomass, suggest that the unimodal relationship between productivity (POC flux) and local diversity holds both within and across regions. Deep-sea regional diversity can influence local diversity (e.g. Stuart \& Rex 1994) and may, therefore, have contributed to the pattern we observed across regions. However, because the relationship holds true when tested at the scale of the Chatham Rise sites, ecological factors acting at smaller spatial scales are more likely to be the main drivers. For instance, diversity at the least productive sites is likely to be limited by generally low population densities with consequently higher probability of local extinction (e.g. Rosenzweig 1995, Rex et al. 2005). This is unlikely to be the only factor involved, however, since the unimodal relationship between biomass and diversity remained significant after accounting for nematode abundance. A variety of factors could be invoked to explain the low diversity at the most productive sites. Increased rates of competitive exclusion may be responsible (Rex 1983), but this possibility has not yet been tested in the deep sea. Highly productive benthic habitats are usually characterized by low oxygen concentrations and high sulphide levels, conditions which are often associated with low infaunal diversity (Bagarinao 1992, Levin 2003). Hydrothermal vents and seeps, probably the most extreme examples of such habitats in the deep sea, are usually characterized by low-diversity nematode assemblages, and are sometimes dominated by species of the family Monhysteridae and of the genus Sabatieria, respectively (Vanreusel et al. 2010). These taxa were also dominant at our most productive deep-sea sites: the Atacama Trench (Gambi et al. 2003), Kaikoura Canyon, Chatham Rise pockmark and the deepest site on the Ross Sea continental shelf (D. Leduc unpubl. data). Physical disturbance may also help explain the low diversity observed at some of the most productive sites (Widdicombe \& Austen 2001). Canyon communities, for example, are often subject to repeated disturbance following sediment resuspension and deposition events along the canyon axis (e.g. De Stigter et al. 2007). Chronic disturbance could help explain the particularly low diversity observed at the shallower (400-700 m water depth) Kaikoura Canyon sites nearest the active head of the canyon (see Table 1). Variability in food availability may also depress diversity at high-productivity sites. High-productivity sites usually experience greater temporal variability in organic matter input, which may favour species able to quickly exploit pulses of phytodetritus and thus lead to lower diversity through competitive exclusion (Chown \& Gaston 1999). Considerable temporal variability in current flows on the Chatham Rise, for example, may lead to highly episodic phytodetritus deposition events (Nodder et al. 2007), a process which may be accentuated by local seabed topography (S. Nodder unpubl.).

It has been suggested that the shape of the unimodal productivity-diversity relationship may be better conceived as an upper boundary rather than a line of fitted average values (Schmid 2002; see also Fig. 2). Gray (2002) also suggested that the role of productivity may lie primarily in setting the upper limit of species diversity, with other factors influencing the realised diversity at a given location. Habitat heterogeneity, for example, is thought to facilitate species coexistence and increase diversity (e.g. Rosenzweig 1995, Henry \& Roberts 2007). The positive influence of habitat heterogeneity on diversity may, however, be limited in highly productive environments characterized by toxic sediment conditions (e.g. high sulphide and low oxygen levels) because only a limited number of species will be adapted to such conditions. Similarly, Huston's (1994) dynamic equilibrium model predicts that the effect of disturbance on diversity will be most limited at either productivity extremes. In a practical sense, the range of productivities included in a study may influence our ability to detect a relationship between diversity and other environmental factors. For example, a study of diversity that includes low and/or high productivity extremes but does not account for this situation in 
analyses may be less likely to detect relationships between, say, habitat heterogeneity and diversity or disturbance and diversity than a study limited to the middle range of productivities, because of the overriding effect of productivity extremes on absolute levels of diversity. The 'productivity context' is, therefore, of primary importance when determining (or comparing) the strength and nature of the relationship between diversity and other environmental factors. Thus, such studies should include measures of productivity as a matter of course, or be designed to sample within a limited productivity range.

Acknowledgements. Sample data were generated under the Foundation for Research, Science and Technology (FRST) programme 'Ocean Ecosystems' (C01X0027) and the New Zealand Ocean Survey 20/20 Chatham-Challenger and IPYCAML Ross Sea projects for which we thank the funding agencies, Land Information New Zealand, Ministry of Fisheries, Department of Conservation and NIWA, for permission to use the data. Funding was also provided by FRST through a postdoctoral fellowship to D. Leduc (UOOX0909), and the programmes 'Consequences of Earth-Ocean Change' (C01X0702), 'Coasts \& Oceans OBI' (C01X0501) and 'Impact of Resource Use on Vulnerable Deep-Sea Communities' (CO1X0906). As well as the aforementioned projects, this paper also represents a contribution to the Census of Marine Life CeDAMar project 'Impacts of Productivity Gradients on Biodiversity and Ecosystem Function in the Abyss'. We thank K. Berkenbusch for processing meiofauna samples (TAN0116), and E. Mackay and A. L. Verdier for their help with the preparation of figures. We also thank the other participants of NIWA voyages TAN0116, TAN0705, TAN0707 and TAN0802, the officers and crew of RV 'Tangaroa' and 4 anonymous reviewers for their constructive criticisms of the manuscript.

\section{LITERATURE CITED}

Anderson MJ, Gorley RN, Clarke KR (2008) PERMANOVA+ for PRIMER: guide to software and statistical methods. PRIMER-E, Plymouth

$>$ Bagarinao T (1992) Sulfide as an environmental factor and toxicant: tolerance and adaptations in aquatic organisms. Aquat Toxicol 24:21-62

Balch W, Evans R, Brown J, Feldman G, McClain C, Esaias W (1992) The remote sensing of ocean primary productivity: use of a new data compilation to test satellite algorithms. J Geophys Res 97:2279-2293

Banse K, Postel JR (2003) On using pigment-normalized, light-saturated carbon uptake with satellite-derived pigment for estimating column photosynthesis. Global Biogeochem Cycles 17:art1079 doi:10.1029/2002GB002021

Berkenbusch K, Probert PK, Nodder SD (2011) Comparative biomass of sediment benthos across a depth transect, Chatham Rise, Southwest Pacific Ocean. Mar Ecol Prog Ser 425:79-90

Bett BJ, Vanreusel A, Vincx M, Soltwedel $\mathrm{T}$ and others (1994) Sampler bias in the quantitative study of deep-sea meiobenthos. Mar Ecol Prog Ser 104:197-203
Boucher G, Lambshead PJD (1995) Ecological biodiversity of marine nematodes in samples from temperate, tropical, and deep-sea regions. Conserv Biol 9:1594-1604

Bowden DA, Schiaparelli S, Clark MR, Rickard GJ (2011) A lost world? Archaic crinoid-dominated assemblages on an Antarctic seamount. Deep-Sea Res II 58:119-127

Brown CJ, Lambshead PJD, Smith CR, Hawkins LE, Farley R (2001) Phytodetritus and the abundance and biomass of abyssal nematodes in the central, equatorial Pacific. Deep-Sea Res I 48:555-565

Buesseler KO, Lamborg CH, Boyd PW, Lam PJ and others (2007) Revisiting carbon flux through the ocean's twilight zone. Science 316:567-570

Chase JM, Leibold MA (2002) Spatial scale dictates the productivity-biodiversity relationship. Nature 416:427-430

Chown SL, Gaston KJ (1999) Patterns in procellariiform diversity as a test of species-energy theory in marine systems. Evol Ecol Res 1:365-373

Cook AA, Lambshead PJD, Hawkins LE, Mitchell N, Levin LA (2000) Nematode abundance at the oxygen minimum zone in the Arabian Sea. Deep-Sea Res II 47:75-85

- Corliss BH, Brown CW, Sun X, Showers WJ (2009) Deep-sea benthic diversity linked to seasonality of pelagic productivity. Deep-Sea Res I 56:835-841

> Cosson N, Sibuet M, Galeron J (1997) Community structure and spatial heterogeneity of the deep-sea macrofauna at three contrasting stations in the tropical northeast Atlantic. Deep-Sea Res I 44:247-269

Currie DJ (1991) Energy and large-scale patterns of animal species- and plant species-richness. Am Nat 137:27-49

Danovaro R, Dinet A, Duineveld G, Tselepides A (1999) Benthic response to particulate fluxes in different trophic environments: a comparison between the Gulf of LionsCatalan Sea (western-Mediterranean) and the Cretan Sea (eastern-Mediterranean). Prog Oceanogr 44:287-312

> Danovaro R, Gambi C, Della Groce N (2002) Meiofauna hotspot in the Atacama Trench, eastern South Pacific Ocean. Deep-Sea Res I 49:843-857

Danovaro R, Gambi C, Lampadariou N, Tselepides A (2008a) Deep-sea nematode biodiversity in the Mediterranean basin: testing for longitudinal, bathymetric and energy gradients. Ecography 31:231-244

> Danovaro R, Gambi C, Dell'Anno A, Corinaldesi C and others (2008b) Exponential decline of deep-sea ecosystem functioning linked to benthic biodiversity loss. Curr Biol 18:1-8

> Davy B, Pecher I, Wood R, Carter L, Gohl K (2010) Gas escape features off New Zealand: evidence of massive release of methane from hydrates. Geophys Res Lett 37 : L21309 doi:10.1029/2010GL045184

> De Leo FC, Smith CR, Rowden AA, Bowden DA, Clark MR (2010) Submarine canyons: hotspots of benthic biomass and productivity in the deep sea. Proc Biol Sci 277: 2783-2792

- De Stigter HC, Boer W, de Jesus Mendes PA, Jesus CC, Thomsen L, van den Bergh GD, van Weering TCE (2007) Recent sediment transport and deposition in the Nazaré Canyon, Portuguese continental margin. Mar Geol 246:144-164

DeMaster DJ, Pope RH, Levin LA, Blair NE (1994) Biological mixing intensity and rates of organic carbon accumulation in North Carolina slope sediments. Deep-Sea Res II 41:735-753

Dinet A, Vivier MH (1979) Le méiobenthos abyssal du Golfe de Gascogne: les peuplements de nématodes et leur diversité spécifique. Cah Biol Mar 20:109-123 
Dodson SI, Arnott SE, Cottingham KL (2000) The relationship in lake communities between primary productivity and species richness. Ecology 81:2662-2679

Etter RJ, Grassle JF (1992) Patterns of species diversity in the deep sea as a function of sediment particle size diversity. Nature 360:576-578

Evans KL, Jackson SF, Greenwood JJD, Gaston JJ (2006) Species traits and the form of individual species-energy relationships. Proc Biol Sci 273:1779-1787

Feller RJ, Warwick RM (1988) Energetics. In: Higgins RP, Thiel $\mathrm{H}$ (eds) Introduction to the study of meiofauna. Smithsonian Institution Press, Washington, DC, p 181-196

> Fonseca G, Soltwedel T (2007) Deep-sea meiobenthic communities underneath the marginal ice zone off Eastern Greenland. Polar Biol 30:607-618

Fonseca G, Soltwedel T (2009) Regional patterns of nematode assemblages in the Arctic deep seas. Polar Biol 32: 1345-1357

Gallucci F, Moens T, Fonseca G (2009) Small-scale spatial patterns of meiobenthos in the Arctic deep sea. Mar Biodivers 39:9-25

> Gambi C, Vanreusel A, Danovaro R (2003) Biodiversity of nematode assemblages from deep-sea sediments of the Atacama Slope and Trench (South Pacific Ocean). DeepSea Res I 50:103-117

Garcia R, Koho KA, De Stigter HC, Epping E, Koning E, Thomsen L (2007) Distribution of meiobenthos in the Nazaré canyon and adjacent slope (western Iberian Margin) in relation to sedimentary composition. Mar Ecol Prog Ser 340:207-220

Giere O (2009) Meiobenthology: the microscopic motile fauna of aquatic sediments. Springer-Verlag, Berlin

> Gray JS (2002) Species richness of marine soft sediments. Mar Ecol Prog Ser 244:285-297

> Grime JP (1973) Competitive exclusion in herbaceous vegetation. Nature 242:344-347

Gross K, Cardinale BJ (2007) Does species richness drive community production or vice versa? Reconciling historical and contemporary paradigms in competitive communities. Am Nat 170:207-220

> Grove SL, Probert PK, Berkenbusch K, Nodder SD (2006) Distribution of bathyal meiofauna in the region of the Subtropical Front, Chatham Rise, south-west Pacific. J Exp Mar Biol Ecol 330:342-355

> Haedrich RL, Rowe GT, Polloni PT (1980) The megabenthic fauna in the deep sea south of New England, USA. Mar Biol 57:165-179

> Hansell DA, Kadko D, Bates NR (2004) Degradation of terrigenous dissolved organic carbon in the western Arctic Ocean. Science 304:858-861

> Hecker B (1990) Photographic evidence for the rapid flux of particles to the sea floor and their transport down the continental slope. Deep-Sea Res 37:1773-1782

Henry LA, Roberts JM (2007) Biodiversity and ecological composition of macrobenthos on cold-water coral mounds and adjacent off-mound habitat in the bathyal Porcupine Seabight, NE Atlantic. Deep-Sea Res I 54:654-672

Hurlbert SH (1971) Nonconcept of species diversity: critique and alternative parameters. Ecology 52:577-586

Huston MA (1994) Biological diversity: the coexistence of species on changing landscapes. Cambridge University Press, Cambridge

- Huston MA (1999) Local processes and regional patterns: appropriate scales for understanding variation in the diversity of plants and animals. Oikos 86:393-401
Jahnke RA (1996) The global ocean flux of particulate carbon: areal distribution and magnitude. Global Biogeochem Cycles 10:71-88

Jensen P (1988) Nematode assemblages in the deep-sea benthos of the Norwegian Sea. Deep-Sea Res 35: 1173-1184

Johnson NA, Campbell JW, Moore TS, Rex MA, Etter RJ, McClain CR, Dowell MD (2007) The relationship between the standing stock of deep-sea macrobenthos and surface production in the western North Atlantic. Deep-Sea Res I 54:1350-1360

> Lambshead PJD, Boucher G (2003) Marine nematode deepsea biodiversity - hyperdiverse or hype? J Biogeogr 30: 475-485

- Lambshead PJD, Tietjen J, Ferrero T, Jensen P (2000) Latitudinal diversity gradients in the deep sea with special reference to North Atlantic nematodes. Mar Ecol Prog Ser 194:159-167

Lambshead PJD, Brown CJ, Ferrero TJ, Mitchell NJ, Smith CR, Hawkins LE, Tietjen J (2002) Latitudinal diversity patterns of deep-sea marine nematodes and organic fluxes: a test from the central equatorial Pacific. Mar Ecol Prog Ser 236:129-135

Lampadariou N, Tselepides A (2006) Spatial variability of meiofaunal communities at areas of contrasting depth and productivity in the Aegean Sea (NE Mediterranean). Prog Oceanogr 69:19-36

- Lawton JH (1996) Patterns in ecology. Oikos 75:145-147

Leduc D, Probert PK, Berkenbusch K, Nodder SD, Pilditch CA (2010a) Abundance of small individuals influences the effectiveness of processing techniques for deep-sea nematodes. Deep-Sea Res I 57:1363-1371

> Leduc D, Probert PK, Nodder SD (2010b) Influence of mesh size and core penetration on estimates of deep-sea nematode abundance, biomass, and diversity. Deep-Sea Res I 57:1354-1362

Leduc D, Rowden AA, Probert PK, Pilditch CA and others (2012) Further evidence for the effect of particle size diversity on deep-sea benthic biodiversity. Deep-Sea Res I 63:164-169

Levin LA (2003) Oxygen minimum zone benthos: adaptation and community response to hypoxia. Oceanogr Mar Biol Annu Rev 41:1-45

Levin LA, Gage JD (1998) Relationships between oxygen, organic matter and diversity of bathyal macrofauna. Deep-Sea Res II 45:129-163

- Levin LA, Etter RJ, Rex MA, Gooday AJ and others (2001) Environmental influences on regional deep-sea species diversity. Annu Rev Ecol Syst 32:51-93

> Lutz MJ, Caldeira K, Dunbar RB, Behrenfeld MJ (2007) Seasonal rhythms of net primary production and particulate organic carbon flux to depth describe the efficiency of biological pump in the global ocean. J Geophys Res 112: C10011 doi:10.1029/2006JC003706

> McClain CR, Barry JP (2010) Habitat heterogeneity, disturbance, and productivity work in concert to regulate biodiversity in deep submarine canyons. Ecology 91: 964-976

Mittelbach GG, Steiner CF, Scheiner SM, Gross KL and others (2001) What is the observed relationship between species richness and productivity? Ecology 82:2381-2396

Mokievskii VO, Udalov AA, Azovsky AI (2007) Quantitative distribution of meiobenthos in deep-water zones of the world ocean. Oceanology 47:797-813 
Murphy RJ, Pinkerton MH, Richardson KM, BradfordGrieve JM (2001) Phytoplankton distributions around New Zealand derived from SeaWiFS remotely-sensed ocean colour data. NZ J Mar Freshw Res 35:343-362

- Nodder SD, Pilditch CA, Probert PK, Hall JA (2003) Variability in benthic biomass and activity beneath the Subtropical Front, Chatham Rise, SW Pacific Ocean. Deep-Sea Res I 50:959-985

> Nodder SD, Duineveld GCA, Pilditch CA, Sutton PJ and others (2007) Focusing of phytodetritus deposition beneath a deep-ocean front, Chatham Rise, New Zealand. Limnol Oceanogr 52:299-314

> O'Hara TD, Tittensor DP (2010) Environmental drivers of ophiuroid species richness on seamounts. Mar Ecol 31:26-38

> Preston FW (1962) The canonical distribution of commonness and rarity: Part II. Ecology 43:410-432

> Probert PK, McKnight DG (1993) Biomass of bathyal macrobenthos in the region of the Subtropical Convergence, Chatham Rise, New Zealand. Deep-Sea Res I 40: 1003-1007

> Pusceddu A, Gambi C, Zeppilli D, Bianchelli S, Danovaro R (2009) Organic matter composition, metazoan meiofauna and nematode biodiversity in Mediterranean deep-sea sediments. Deep-Sea Res II 56:755-762

Quinn PQ, Keough MJ (2009) Experimental design and data analysis for biologists. Cambridge University Press, Cambridge

Rex MA (1973) Deep-sea species diversity: decreased gastropod diversity at abyssal depths. Science 181:1051-1053

Rex MA (1976) Biological accommodation in the deep-sea benthos: comparative evidence on the importance of predation and productivity. Deep-Sea Res 23:975-987

$>$ Rex MA (1981) Community structure in the deep-sea benthos. Annu Rev Ecol Syst 12:331-353

Rex MA (1983) Geographic patterns of species diversity in the deep-sea benthos. In: Rowe GT (ed) The sea, Vol 8. Deep-sea biology. Wiley, New York, NY, p 453-472

Rex MA, Etter RJ (2010) Deep-sea diversity: pattern and scale. Harvard University Press, Cambridge, MA

Rex MA, Crame JA, Stuart CT, Clarke A (2005) Large-scale biogeographic patterns in marine molluscs: a confluence of history and productivity? Ecology 86:2288-2297

Rosenzweig ML (1992) Species diversity gradients: we know more and less than we thought. J Mammal 73:715-730

Rosenzweig ML (1995) Species diversity in space and time. Cambridge University Press, Cambridge

Rosenzweig ML, Abramsky Z (1993) How are diversity and productivity related? In: Rickleffs RE, Schluter D (eds) Species diversity in ecological communities: historical and geographical perspectives. University of Chicago Press, Chicago, IL, p 52-65

Rowe GT, Wei C, Nunnally C, Haedrich R and others (2008) Comparative biomass structure and estimated carbon flow in food webs in the deep Gulf of Mexico. Deep-Sea Res II 55:2699-2711

> Schmid B (2002) The species richness-productivity controversy. Trends Ecol Evol 17:113-114

Smith CR, Berelson W, DeMaster DJ, Dobbs FC and others (1997) Latitudinal variations in benthic processes in the abyssal equatorial Pacific: control by biogenic particle flux. Deep-Sea Res II 44:2295-2317

Smith CR, De Leo FC, Bernardino AF, Sweetman AK, Martinez-Arbizu P (2008) Abyssal food limitation, ecosystem structure and climate change. Trends Ecol Evol 23: 518-528

Snelgrove PVR, Grassle JF, Petrecca RF (1994) Macrofaunal response to artificial enrichments and depressions in a deep-sea habitat. J Mar Res 52:345-369

Soetaert K, Heip C (1995) Nematode assemblages of deepsea and shelf break sites in the North Atlantic and Mediterranean Sea. Mar Ecol Prog Ser 125:171-183

Somerfield P, Warwick RM (1996) Meiofauna in marine pollution monitoring programmes: a laboratory manual. Ministry of Agriculture, Fisheries, and Food, Lowestoft

Stuart CT, Rex MA (1994) The relationship between development pattern and species diversity in deep-sea prosobranch snails. In: Young CM, Eckelbarger KJ (eds) Reproduction, larval biology, and recruitment in the deep-sea benthos. Columbia University Press, New York, NY, p 119-136

> Stuart CT, Rex MA (2009) Bathymetric patterns of deep-sea gastropod species diversity in 10 basins of the Atlantic Ocean and Norwegian Sea. Mar Ecol 30:164-180

Sutton P (2001) Detailed structure of the Subtropical Front over Chatham Rise, east of New Zealand. J Geophys Res 106:31045-31056

Tietjen JH (1984) Distribution and species diversity of deepsea nematodes in the Venezuela Basin. Deep-Sea Res 31: 119-132

> Tietjen JH (1989) Ecology of deep-sea nematodes from the Puerto Rico Trench area and Hatteras Abyssal Plain. Deep-Sea Res A 36:1579-1594

Tittensor DP, Rex MA, Stuart CT, McClain CR, Smith CR (2011) Species-energy relationships in deep-sea molluscs. Biol Lett 7:718-722

> Usbeck R, Schlitzer R, Fischer G, Wefer G (2003) Particle fluxes in the ocean: comparison of sediment trap data with results from inverse modelling. J Mar Syst 39:167-183

> Vanreusel A, De Grote A, Gollner S, Bright M (2010) Ecology and biogeography of free-living nematodes associated with chemosynthetic environments in the deep sea: a review. PLoS ONE 5:e12449

> Waide RB, Willig MR, Steiner CF, Mittelbach G and others (1999) The relationship between productivity and species richness. Annu Rev Ecol Syst 30:257-300

Warwick RM, Platt HM, Somerfield PJ (1998) Free-living marine nematodes. Part III. Monhysterids. Synopses of the British fauna (new series), 53. Cambridge University Press, Cambridge

Wei C, Rowe GT, Escobar-Briones E, Boetius A and others (2010) Global patterns and predictions of seafloor biomass using Random Forests. PLoS ONE 5:e15323

> Widdicombe S, Austen MC (2001) The interaction between physical disturbance and organic enrichment: an important element in structuring benthic communities. Limnol Oceanogr 46:1720-1733

Witman JD, Cusson M, Archambault P, Pershing AJ, Mieszkowska N (2008) The relation between productivity and species diversity in temperate-arctic marine ecosystems. Ecology 89:S66-S80

> Wright DA (1983) Species-energy theory: an extension of species-area theory. Oikos 41:496-506

> Zardus JD, Etter RJ, Chase MR, Rex MA, Boyle EE (2006) Bathymetric and geographic population structure in the pan-Atlantic deep-sea bivalve Deminucula atacellana (Schenk, 1939). Mol Ecol 15:639-651 